\title{
Russians from China: Migrations and Identity
}

\author{
Mara Moustafine, University of Technology Sydney, NSW, Australia
}

\begin{abstract}
In the first half of the 20th century, sizeable Russian communities lived in a number of Chinese cities, including Harbin, Shanghai and Tientsin. The largest and most diverse of these was the community that grew up around Harbin in north China. By the mid 1920s, Harbin was home to one of the largest Russian diaspora communities in the world, with over 120,000 Russians and other nationalities from the former Tsarist Empire. Moreover, many Russians in Shanghai and Tientsin had links to Harbin, as their first place of domicile in China. By the late 1950s, political transformations in China had driven almost all these people elsewhere. But for many of them, their roots in China became a key aspect of their identity in emigration in their new diasporas. This paper explores the background to this unique community and the geo-political forces underpinning the various waves of migration of Russians into and out of Harbin. It analyses the complex issues of identity and citizenship Russians faced while living in Harbin, their fates determined at various points in time by the dominance of three powers - Russia, China and Japan. Drawing on the experience of my own family, whose life in Harbin and Manchuria spanned four generations over fifty years, it touches on the rich ethnic and cultural mix that lay beneath the surface of "Russian" Harbin, with particular reference to the Jewish community that once thrived there. Finally, it examines how the 'Harbintsy' perceive their identity in emigration and the recent changes in attitude towards them of the Chinese authorities.
\end{abstract}

Keywords: Russian, China, Harbin, Manchuria, Japan, Jews, Diversity, Migration, Identity, Diaspora, Cosmopolitan, Multicultural

\section{Introduction}

TN THE FIRST half of the $20^{\text {th }}$ century, sizeable Russian communities lived in a number of Chinese cities, including Harbin, Shanghai and Tientsin ${ }^{1}$. The largest and most diverse of these was the community that grew up around the city of Harbin in north China, then known as Manchuria to Europeans and Dongbei to the Chinese. By the mid 1920s, this region was home to one the largest Russian diaspora communities in the world, with 120,000 living in Harbin and some 35,000 in other settlements in Manchuria (Stephan 1978, pp. 96109). The Harbin community was comprised of ethnic Russians, as well as other nationalities from the former Tsarist Empire, living in relative harmony in a "Russian world" on Chinese soil $^{2}$.

Harbin's Russian history began in 1898 with the construction of the Chinese Eastern Railway (CER) across Manchuria, linking the Trans-Siberian Railway to Vladivostok. As part of a deal struck in 1896 with the government of Qing China, Russia gained a concession to build and operate the railway in return for a secret defence pact against Japan. With this came extraterritorial rights in the five mile zone along the route of the railway - the CER

\footnotetext{
${ }^{1}$ In the mid 1930s, the Russian communities of Shanghai and Tientsin were estimated to number around 21,000 (Wang 2008, p. 94) and 6,000 (Balakshin 1958, p.236) respectively.

${ }^{2}$ Much of the information in this paper is drawn from (Moustafine 2002)
}

The International Journal of Diversity in Organisations, Communities and Nations Volume 9, Number 6, 2010, http://www.Diversity-Journal.com, ISSN 1447-9532 (C) Common Ground, Mara Moustafine, All Rights Reserved, Permissions: cg-support@commongroundpublishing.com 
zone. Manchuria, in effect, became a Russian colony, and Harbin, where the headquarters of the CER Administration was located, its de facto capital ${ }^{3}$.

\section{Waves of Inward Migration}

\section{1898-1917 to Build the CER and Develop Russian Manchuria}

The CER drew tens of thousands of people from the far reaches of the Tsarist Empire to the largely wild and sparsely populated steppes of Manchuria. Engineers and labourers came to build the railway; clerks, guards and civil servants to work in its administration. Merchants and traders came to develop natural resources and provide goods and services in Harbin and other Russian settlements along the railway's route. Large numbers of Chinese "coolies" were also brought in from Shandong province in southern China as construction labour.

During the Russo-Japanese War of 1904-1905, Harbin was a base for Russian military operations in Manchuria, supplying the Tsar's 950,000-strong army with provisions and serving as a hospital and rest and recreation centre, with a garrison for some 100,000 troops. After demobilisation, some of the soldiers returned to live in Manchuria with their families (Wolff 1999, pp. 121-125).

Harbin was a distinctly Russian city in China. Its architecture was reminiscent of Moscow or St. Petersburg, with onion-domed cupolas, empire-style façades, wide boulevards and touches of art nouveau. Russian was spoken in the streets, shops and theatres. It was also the language of administration, commerce and education. Street signs and billboards were written in Russian. Only in Fujiadian, where most of Harbin's Chinese lived and few Russians ventured, did Chinese prevail. ${ }^{4}$

From its early days, "Russian" Harbin was a community of diverse cultures and ethnicities united by their origins in the Russian empire. It was multicultural and cosmopolitan ${ }^{5}$. Keen to attract entrepreneurs and private investors to drive the rapid economic development of Manchuria, the St Petersburg authorities deliberately created an environment of tolerance, equal opportunity and actively encouraged minorities of the Tsarist Empire to come and live there $^{6}$. Settlers of various cultures and religions flocked there in search of a better life, among them Jews, Poles, Tatars, Georgians, Armenians and Ukrainians (Chernolutskaya 2000). Harbin offered them a Russian-speaking cultural, social and economic world, without the official boundaries and prejudices of the Russian state.

\section{Jews}

The case of the Jews, who in 1903 were the earliest minority community officially recognised by the CER Administration and who continued as an organised community until 1964, demonstrates the way in which this cosmopolitan dynamic developed. For Jews of the Tsarist Empire, Russian Manchuria was the land of opportunity. The discriminatory laws

\footnotetext{
${ }^{3}$ For a background to the CER and early history of Manchuria, see (Quested 1982), (Melikhov 1991), (Wolff 1999).

${ }^{4}$ See (Melikhov 1990) (Taskina 1994) re Russian life in Harbin; (Balakshin 1958) for an account of émigré politics between 1917 and 1945.

${ }^{5}$ According to the 1913 census, there were 22 nationalities living in the commercial Pristan district of Harbin (half of them minorities of the Tsarist empire) (Levitsky 2000, p. 47)

${ }^{6}$ See (Wolff 1999, pp. 78-90) re internal debate in the Tsarist government regarding settler policy in the CER.
} 
and restrictions which prevailed in the empire proper - like those confining them to live in the Pale of Settlement ${ }^{7}$, excluding them from certain professions and setting quotas for their numbers in schools and other educational institutions - did not apply there ${ }^{8}$. Most importantly, there were no pogroms and little overt anti-Semitism, at least until the late 1920s. Efforts to impose restrictions on the Jews were actively opposed by the CER Chief Administrator, General Horvath ${ }^{9}$.

Jews started coming to Manchuria from 1898 and played an early role in developing natural resources (lumber, coal, flour mills, distillery, sugar refining, meat \& livestock), freight based export industries (grain, soya bean oil, wool, skins, furs) and commerce (hotels, restaurants, music stores, jewelers, pharmacies). Small communities sprang up in the small towns along the railway at Hailar, Manchuria Station, Mukden and Tsitsihar, but most settled in Harbin.

They quickly established their own community institutions (schools, a synagogue, a burial society and communal dining room) and played an active role in the commercial, cultural and public life of Russian Harbin. They also participated actively in Harbin's municipal affairs - making up 12 of the 40 members on the city council in 1909 (Kaufman 2001). Although there is no evidence of Jews being employed by the CER before 1915, this may have been in deference to the hiring practice in Russian state enterprises, as there was no law to this effect (Wolff 1999, pp. 104, 222).

Chain migration was common, with one member of an extended family coming first to test opportunities in the distant new homeland, then others following. So it was, with the families of my maternal grandparents from Byelorussia, who arrived in Harbin in the first decade of the $20^{\text {th }}$ century. My grandfather's family established a successful meat and livestock business in Harbin, while my grandmother's family settled in the town of Hailar, near the Russian border, where they had a small dairy business (Moustafine 2004).

\section{Refugees from Bolshevik Revolution, Civil War and Collectivisation 1917 - 1930}

The second major influx of Russians into Harbin came in the wake of the 1917 Bolshevik Revolution and the ensuing Civil war. At its height, Harbin and the CER zone served as a staging ground for White armies in their battle with the Bolsheviks in Siberia. After the White defeat in 1922, masses of people who had spent the civil war in Siberia, including my paternal grandparents, came across the border with the retreating White Armies. Stalin's forced collectivisation campaign (1928-31) brought more refugees on the dangerous journey from Siberia across the Amur River. ${ }^{10}$

Among the thousands of refugees who flooded into Harbin were people from all walks of life and diverse nationalities: from former royalty to anti-Bolshevik White Guards and Cossacks, as well as poor unskilled labourers. The influx of artists, musicians and intellectuals endowed it with a rich cultural life. At its peak in the mid 1920s, the Russian community

\footnotetext{
${ }^{7}$ The western border area of the Tsarist empire, stretching from the Baltic to the Black Sea.

${ }^{8}$ On Jewish community, see (Bresler 2000), (Shickman-Bowman 2000), (Wolff 1999, pp. 96-106), (Kaufman 2006)

${ }^{9}$ The former leader of the Harbin Jewish community, Dr A. I. Kaufman described an instance when Horvath thwarted such an attempt by the Governor-general of the Far Eastern Province, Gondatti. (Kaufman 2001, p. 34). ${ }^{10}$ In 1926 the border was closed on the Soviet side and in 1932 on the Chinese side by the occupying Japanese. (Kaufman 2006, p. 30)
} 
numbered about 120,000 people, with another 35,000 living in the smaller towns along the railway's route $^{11}$. By this time the Jewish community in Harbin had grown to around 13,000, with around 2,000 in other towns - comprising some 10 per cent of the Russian population. They now boasted two synagogues and had extended their communal institutions (Bresler 2000).

As a conspicuously Russian city in China - in terms of architecture, language and culture - Harbin provided Russian refugees with a semblance of familiarity. Still, this could not overcome the deep sense of displacement and loss which the refugees felt as they strived to come to terms with broken families, loss of loved ones, homeland and often status.

\section{Citizenship and Identity 1898 - 1930}

Before the 1917 Bolshevik Revolution, issues of identity and citizenship ${ }^{12}$ for Russian Harbintsy ${ }^{13}$ were quite straightforward. Arriving from the Russian empire on Tsarist passports, they regarded themselves as Russians or Russian Jews living in the CER Zone Russia's "colony" in Manchuria. Some saw their residence in Harbin as temporary. For others, it was their new home, a place where they could live in a Russian-speaking cultural, social and economic world, without the official boundaries and prejudices of the Russian state.

While the political status of the CER zone remained undecided, anti-Bolshevik White Russians and Chinese warlords were in effective control. In 1920 the Chinese Republican Government withdrew recognition from Tsarist representatives to China and ended Russian extraterritoriality in the CER zone, leaving Russians in Manchuria stateless (Bakich 2000; Quested 1982).

In June 1924, the Chinese finally recognised the Soviet government and the two powers agreed that henceforth they would jointly administer the CER, and that Chinese law would apply. In practical terms, the Soviets were in control of the administration of the CER, including the railway, schools, hospitals and other institutions ${ }^{14}$. It was decreed that only Soviet or Chinese citizens could work for the CER, a reasonable requirement for what was effectively the civil service in the CER zone. Around 20,000 CER employees registered with the Soviet Consulate to preserve their jobs. Many of them were jokingly called "radishes" - Red on the outside, White on the inside. A small number took Chinese citizenship (Bakich 2000, pp. 17-18); (Lensen 1974, pp. 17-18). Those who preferred to remain stateless began to seek work elsewhere.

By the early 1930s, with their old Tsarist passports obsolete, Russians who did not work for the CER administration also started to consider their citizenship. Their choices were to register as Soviet or Chinese citizens, or to remain stateless. Out of patriotism to the old Russia and opposition to the Bolsheviks, most chose to remain stateless - "White émigrés".

\footnotetext{
${ }^{11}$ According to (Bakich 2000, p. 56), between 100,000 and 200,000 Russian émigrés flooded into Harbin during this period, though many moved on to other cities in China and beyond. (Stephan 1978, p. 56) puts Harbin's Russian population at 120,000 in 1922 , plus some 13,000 Jews.

12 (Bakich 2000) provides an interesting analysis of these issues.

${ }^{13}$ Harbintsy is the Russian word for "people of Harbin", cf. Berliners, New Yorkers, Muscovites. It applies to any nationality, not just Russians. Although the paper focuses on Russian Harbintsy, many of their experiences were shared by Russians living elsewhere in "Russian Manchuria".

${ }^{14}$ This situation prevailed for the next seven years, except for a brief period during the Sino-Soviet conflict in 1929 (Lensen 1974, pp. 13-81)
} 
A few became Soviet citizens out of sympathy for the revolution. Quite a number of longterm settlers, like my mother's family, chose the Soviet option simply to avoid being stateless in the turbulent times in which they lived. Registering with the Soviet Consulate did not entitle these people to full rights as Soviet citizens, or even the right to emigrate to the USSR. The little brown clothbound books with which they were issued looked like passports but were, in fact, 'residence permits' which gave them the protection of the Soviet Consulate while living in China.

At this stage, these citizenship choices had little impact on the lives of Russian Harbintsy, other than in terms of their employment opportunities. They continued to live side by side, to mix socially and to do business with each other. Still, from this time onwards, concerns about citizenship and identity left many Harbintsy insecure about their place in society, a sense which would continue for their remaining years in Harbin. The division into White émigrés and Soviets would have far-reaching consequences during the 13 years of Japanese occupation (Bresler 2000, p. 204), (Melikhov 1997, pp. 199-200).

\section{Waves of Outward Migration 1931-1960s}

From its inception at the turn of the $20^{\text {th }}$ century, the city of Harbin served both as a transit point for people escaping the confines of the Russian or Soviet empire to the world beyond and as an end point for those who wished to seek their fortunes in China. Even before the Bolshevik Revolution, many Russians took the Chinese Eastern Railway from Siberia to Harbin, then travelled to the treaty ports of Shanghai and Tientsin, as well as other points in Asia and even Australia. But a majority stayed on in Harbin and other towns in Manchuria, where they built a new life and contributed to the economic and cultural development of the CER zone.

A sequence of major political transformations in China, driven by the three powers competing for hegemony in Manchuria - Japan, the Soviet Union and China itself - prompted the exodus of Russians from the region. These were the Japanese occupation of Manchuria in 1932, the Soviet Union's sale of the CER to Japan in 1935, occupation by the Soviet Red Army in 1945 and finally, the Chinese Communist Revolution in 1949.

\section{Japanese Occupation of Manchuria-Manchukuo-1932-1945}

The Japanese occupation of Manchuria and the establishment of the puppet Manchukuo regime in 1932 fractured Harbin's "Russian world", driving many Russian Harbintsy to seek refuge elsewhere. Many moved to other cities in China, notably the international settlements in Shanghai and Tianjin ${ }^{15}$. Others went to the Soviet Union. By the end of the 1930s, the Russian population of Harbin had dropped to around $30,000^{16}$.

As part of their effort to gain control of the CER and drive the Soviets out of Manchuria, the Japanese military police began a campaign of harassment of CER employees and other Soviet citizens, through attacks and arrests. This became most pronounced after the Soviet Union sold the CER enterprise to Japan in March 1935, as did the polarisation of the Russian community into White émigrés and Soviets (Lensen 1974, pp. 212-334).

\footnotetext{
${ }^{15}$ The Japanese did not take over these cities until the end of 1937.

${ }^{16}$ This figure is based on Japanese data given in ('The White Russians of Manchukuo' 1937); (Clausen \& Thøgersen 1995, p. 116).
} 
Life for Jews in Manchuria too deteriorated seriously after the Japanese occupation. The Japanese themselves were not driven by anti-Semitism and publicly maintained good relations with the Jewish community. But they associated closely with militant anti-Soviet Whites, such as the Russian Fascist Party (RFP), whose ideology of anti-Bolshevism and nationalism was laced with virulent anti-Semitism ${ }^{17}$. In the early 1930s, Russian thugs linked to the RFP engaged in a campaign of kidnappings, extortion and murder against wealthy businessmen, mainly Jews, masterminded by the Japanese military police, the Kempeitai ${ }^{18}$. Their spree culminated in 1933 with the kidnap and brutal murder of the accomplished Jewish pianist Simon Kaspe, whose father owned Harbin's Hotel Moderne (Vespa 1938); (Stephan 1978, pp. 78-90); (Breuillard 2004).

Faced with a declining economy, banditry, anti-Semitism, political intimidation and the takeover of their businesses by the Japanese, over half of its Jewish population left Harbin. Many moved to other cities in China, notably the international settlements in Shanghai and Tianjin, as well as the Soviet Union. By 1935, Harbin's Jewish community had declined from 13,000 in 1931 to only 5,000 (Bresler 2000, p. 209).

\section{Soviet Sale of CER to Japan 1935}

In March 1935 the Soviet Union sold the CER enterprise to Japan, losing its influence and ability to protect the interests of its citizens in Manchuria for the next decade. A mass exodus of Russians from Harbin followed, as some 30,000 families departed for the Soviet Union on overcrowded trains strung with banners reading "Mother Russia, receive your children". Most were CER employees but there were also those who felt there was no future for Russians in Manchuria ${ }^{19}$, among them my grandmother's parents and siblings.

For many of these people, their identity as Harbintsy proved to be a death warrant. As xenophobia against foreign enemies grew at the height of Stalin's Great Terror, they were arrested as "Japanese spies" under NKVD Chief Yezhov's special Harbin order of September $1937^{20} .48,000$ Harbintsy were arrested, 31,000 of them executed; the rest sent to labour camps $^{21}$.

\section{Citizenship and Identity in Manchukuo}

For the Russians who remained in Harbin during the 13 years of Japanese occupation, citizenship and identity became paramount as the community was polarised over these issues. Suddenly people who for years had lived side by side, united by their Russian origins, became

\footnotetext{
${ }^{17}$ (Stephan 1978) provides a fascinating account of the role the RFP played in the politics of Manchuria. The roots of their ideology and collaboration with the Japanese are described on pages 55-78.

18 (Bresler 2000, p. 209) notes that eight of the 12 people kidnapped between 1932 and 1934 were Jews and four of them were murdered.

${ }^{19}$ Exact numbers of "returnees" are unknown and estimates vary between 21,000 and 100,000. See discussion in (Merritt 1998).

${ }^{20}$ Operational Order No. 00593 of 20 September 1937. An English translation appears in (Moustafine 2002, pp. 449-452). Merritt (1998) provides an interesting analysis in the context of the purges.

${ }^{21}$ These statistics, based on research work by A. B. Roginsky and O. A. Gorlanov of Memorial's Research and Information Centre, were provided to me in May 2002. My book Secrets and Spies: The Harbin Files (2002) tells this story, based on the secret police files of my family which I obtained from the FSB after the collapse of the Soviet Union.
} 
identified by the characteristics which divided them: 'White émigré' or 'Soviet', 'Orthodox Christian' or 'Jew'.

In garnering support of Russian émigrés for their occupation, the Japanese rekindled old dreams and prejudices. In 1934 the Japanese established the Bureau of Russian Émigré Affairs in Manchukuo (BREM) as a mechanism of controlling the Russian population in Manchuria. Nominally under Russian control, it was headed by a succession of White Army generals and run by members of the RFP and their sympathisers, thereby giving implicit sanction to their anti-Bolshevik and anti-Semitic ideology 22 .

All adult émigré Russians were required to register with the BREM ${ }^{23}$. Only then could they receive identity papers, residence permits, employment cards and travel documents. Those who did not were denied employment and education for their children. In the later years of the occupation, Russian émigrés were issued with identification badges - at first, striped white, blue and red like the Tsarist flag, later, round, white aluminium disks, with numbers, which the wearers labelled "dog tags". ${ }^{24}$ Soviets were instantly conspicuous because they had no badges. Faced with such pressures, many Soviets, including former employees of the CER administration and some prominent merchants, saw no option but to "convert" to émigré status. By the 1940s, through departures and conversions, the number of Soviet Harbintsy had dwindled to around 1,000 (Stephan 1978, p. 176).

My mother's family were among those who retained Soviet citizenship throughout the Japanese occupation, as my grandfather insisted that being stateless - "a citizen of nowhere" - was too risky in the face of Japanese aggression. The price was the seizure of his meat business by the Japanese and my mother's exclusion from school and youth activities. Still, the family fared much better than friends and relatives in Hailar, some of whom were imprisoned by the Japanese as alleged Soviet agents; while others were among the 47 beheaded by the Japanese on the eve of the arrival of the Soviet Red Army in August 1945.

For most émigré Harbintsy, the oppressiveness of Japanese occupation also weighed heavily, particularly after the outbreak of the Second World War. In addition to cultural subservience to the Japanese "Imperial way", the émigré community was expected to help build Japan's new East Asian Order through the conscription of young men into military detachments and the deployment of some in cross-border raids against the Soviet Union. The invasion of the Soviet Union by Japan's ally, Germany in June 1941, severely tested émigré loyalties. Eventually even the most anti-Soviet Whites, who had made common cause with Japan in the hope that White Russian rule would be restored in the Soviet Far East, were left with no illusions that Japan was pursuing anything other than its own interests. ${ }^{25}$

\section{Soviet Army Occupation of Manchuria 1945}

The next migration of Harbintsy was the forced deportation which took place after the Soviet Red Army arrived in August 1945 to "liberate" Manchuria from the Japanese. Most Harbintsy, regardless of their political tags, welcomed them with flowers and euphoria. However, with the arrival of the slick operatives of the military counter-intelligence organisation SMERSH

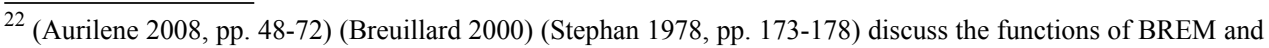
life for émigré Russians under its administration.

${ }^{23}$ Captured by the Soviets in 1945, the BREM files are now held in the Khabarovsk State Archive.

${ }^{24}$ Poles and other citizens of the former Tsarist Empire were issued with yellow badges.

${ }^{25}$ By this time, they had discovered that the Japanese did not include the Russians among the five races for whom they were building Manchukuo (Bakich 2000, p. 62).
} 
(Death to Spies!), thousands of innocent émigrés were rounded up and deported to prison camps in the USSR, along with Japanese collaborators (Bresler 2000, p. 211). Among them were young men who had been conscripted into anti-Soviet military detachments like Asano, as well as representatives of Harbin's various communities and social organisations, who had had dealings with the Japanese on behalf of their communities. This included Jewish community leader Dr Abraham Kaufman (Kaufman 1973); (Kaufman 2006, pp. 131-159); (Pasternak \& Raleigh 1983). Smersh drew its information from the archive of émigré files compiled by BREM.

During its short lived occupation of Manchuria, the Soviet Union established "Soviet" style administration and registered most Russians as "Soviet citizens" (without rights). After the Soviets departed in April 1946, their influence over Russian Harbintsy was maintained through the Society of Soviet Citizens, created to administer the affairs of Russians in Manchuria, much as BREM did during the Japanese years. It operated in close collaboration with the Soviet Consulate, as BREM had with the Japanese Military Mission.

\section{After the 1949 Chinese Communist Revolution}

The final major wave of migration from Harbin came in the wake of the 1949 Chinese communist revolution.

In the mid-1950s, Russian Harbintsy were invited, then pressured, to repatriate to the Soviet Union as part of Khrushchev's "Virgin Lands" campaign. ${ }^{26}$ Some went as patriots, others in the hope of being reunited with loved ones deported in 1945. Most found themselves stranded in the steppes of southern Kazakhstan or the snows of Siberia, though most were later able to find jobs in urban centres. Those who resisted the pressure to go to the USSR were sacked from any Chinese state enterprise employment, but were eventually permitted to migrate to other countries, including Australia, Brazil, Argentina, Israel, Canada and the United States.

By the time my family left for Sydney in 1959, the Russian community in Harbin had dwindled to a couple of thousand, with a couple of hundred Jews. Some of our relatives, unable to secure visas earlier, left China in 1964, bearing the repercussions of the breakdown of relations between China and the Soviet Union in the early 1960s. By that time, fewer than 500 Russians remained in Harbin (Clausen \& Thøgersen 1995, p. 160).

During the Cultural Revolution in China from 1966-1976, Russians who had remained in Harbin found themselves under attack from Red Guards as "foreign devils". Some of them were imprisoned as "Soviet spies". Others were forced to witness the destruction of St Nicholas Cathedral, Harbin's holiest Orthodox religious shrine, blown up in 1966 (Working 2001), and the desecration of tombstones and other churches.

In 1986, one of the surviving Russian Orthodox churches - the Pokrov church - was renovated and reopened for services, which were conducted by a Chinese priest, Father Grigori Zhu. The parishioners included the dwindling number of ethnic Russians, as well as Orthodox Chinese. Father Grigori's death in 2000 has left the church without a priest to

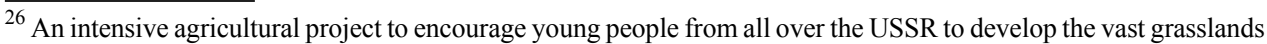
of Kazakhstan and Siberia that had never been farmed before. The programme was extended to Soviet citizens in China in 1954.
} 
conduct services ('Timeline of Orthodoxy in China' 2009). The last of the long term Russian residents died in 2006 at the age of 96.

\section{Beyond Harbin: Identity in Emigration}

After the turbulence and insecurity they had lived with, most Russians from China found welcome respite in their countries of resettlement, blending into the societies around them with relative ease as they embraced the stability they offered. To preserve their religious and cultural heritage, in many places, ethnic Russians established churches and weekend language schools for their children. ${ }^{27}$ They maintained their social links and formed alumni associations, like that of the Harbin Polytechnical Institute, Harbin's main tertiary institution, which published a journal in Australia for over 35 years. Russian Jews from China still keep in touch through The Bulletin of Igud Yotzei Sin, (the Association of Former Jewish Residents of China), established in Israel in the 1950s, with branches all over the world.

For most of these people, Harbin and China remain central to their identity - they call themselves Russians "from China", not simply "Russians". In their literature, they describe themselves as the "Chinese" branch of the Russian or Jewish diaspora. Following the collapse of the Soviet Union, periodicals with names like In the Hills of Manchuria, Russians in China emerged and gained a following among Harbintsy around the world. The pages of these publications are laden with histories of Russian institutions and life in China, personal reminiscences, searches for erstwhile friends, necrologies and nostalgia.

To a large extent, this is not an identification with China itself, but with the world of "Russian Harbin", which the Harbintsy created in the Manchurian hills, then lost. During their years there, most lived in a predominantly Russian world, with little thought for the China around them. Few studied the language seriously or delved into the culture. Most of their interactions with Chinese were confined to their domestic assistants, tradesmen and merchants, who spoke pidgin Russian, or with educated Russian-speaking Chinese. Few ventured into the adjacent district of Fujiadian, where most of Harbin's Chinese then lived. For most Russians, the underlying element was their sense of Harbin's role in preserving the rich cultural heritage of pre-revolutionary Russia, uncontaminated by Soviet influence. ${ }^{28}$ For Russian Jews, their China was one where "Jews could be Russians", free to participate fully in either or both cultures.

Today many former Harbintsy and their children and grandchildren seek to reconnect with their history and rediscover their roots, through genealogical research as well as travel to Harbin. In the last decade, this is being positively encouraged by Chinese authorities.

\section{Attitude of Current Chinese Authorities to Harbin's "Russian" Past}

Harbin's Russian past, which went unmentioned during the Maoist period, was long caught up in the intricacies of the historical, political and ideological rivalry between the Soviet Union and China. The demise of the Soviet Union in 1991 eliminated the ideological dimen-

\footnotetext{
${ }^{27}$ See (Ryan 2005) on language retention in émigré Russian communities.

28 (Stephan 1978, p. 43) "Like excised tissue preserved in formaldehyde long after the parent body has perished, the émigrés of Harbin persisted, a lifelike fragment of the pre-revolutionary era".
} 
sion and the relationship with Russia is now developing along more pragmatic lines, allowing some acknowledgement of the role Russians played in Harbin's development.

Since the late 1990s, efforts have been made to preserve some old Russian buildings and Harbin's daily newspaper, the Heilongjiang Daily, started to run feature articles about former Harbintsy ${ }^{29}$. While Harbin's centenary in 1998 went uncelebrated, a program of civic works was started a year ahead of it. The former Church of St. Sophia was refurbished as the Harbin Architectural Museum, complete with Orthodox crosses on its domes. Zhongyang street, the main street of the Daoli district (formerly Kitayskaya Ulitsa of old Harbin) was converted into a pedestrian mall and many of the buildings spruced up. ${ }^{30}$ The motive was, of course, to attract tourists. But St Sophia has now become a symbol of Harbin, and the museum inside it is a testament to the city's Russian history. Other Russian buildings have also been preserved. The former Tartar Mosque has been refurbished into a functioning place of worship. There is talk of restoring other Russian churches, as relations with Russia are strengthening.

Far less contentious, at least since diplomatic relations with Israel were established in 1992, has been the role of the former Jewish community in Harbin. The last decade has seen concerted efforts to preserve vestiges of Jewish life in Harbin as a priority, endorsed by the provincial and municipal governments. This has resulted in the restoration of Harbin's large Jewish cemetery, where 600 graves have been identified, the refurbishment of one of the former synagogues as an exhibition hall, which now houses a permanent exhibit on the history of the Jews of Harbin, as well regular conferences on similar subjects organised by the Jewish Studies Centre of the Heilongjiang Academy of Social Sciences. ${ }^{31}$

As well as the intrinsic historical and cultural value of this restoration work, the aim is clearly to attract tourists and investors. It is also part of an effort to reposition Harbin in relation to the global economy by linking the city's cosmopolitan past with its drive for a global future.(Koga 2008)

\section{Conclusion}

As headquarters of the Chinese Eastern Railway - Tsarist Russia's last imperial project in the early 1900s, Harbin was transformed from a small fishing village on the Sungari river in north China into a major economic hub. It was a magnet for indigenous Chinese workers from the south, as well as entrepreneurs, adventurers and minorities from across the Tsarist Empire. Though holding a common citizenship, this latter group was multi-national and multi-ethnic. Importantly, the hierarchies that operated within the Empire proper were rapidly eroded in pursuit of economic opportunity and modernisation.

The aftermath of the 1917 Bolshevik Revolution and the civil war that followed brought a massive wave of immigration to the CER Zone, the last remaining Russian enclave outside the Soviet Union. In the absence of clear political authority and defined citizenship in the Zone in the interregnum between Tsarist and Soviet rule in the Russian Empire, the identity of Russians there became strongly focused on locality - they became Harbintsy. This largely continued in the brief period of joint Sino-Soviet control.

\footnotetext{
${ }^{29}$ These have since been published as a book (Zeng 2003)

30 (Berton 1999) notes that a celebration of the anniversary of Zhongyang Street's conversion into a pedestrian mall just happened to coincide with the hundredth anniversary of both the street and Harbin.

${ }^{31}$ The first International Conference on the History and Culture of the Jews of Harbin was held in August 2004.
} 
Harbin was at its peak in the mid 1920s, with a rich Russian cultural life, offset by a unique cosmopolitan flavour and the interplay of ethnic, religious and cultural communities. The emergence of a Harbin identity was most aptly demonstrated in the experience of the Jews, who were able to be both Russian, in their economic, political and cultural practices, and Jewish, in their communal and religious.

The Japanese occupation of Manchuria from the early 1930s turned this Russian world upside down. Arbitrary arrests and intimidation aimed at driving out the Soviets, the polarisation of the Russian community between "reds" and "whites", economic decline and the rise of anti-Semitism prompted the first major exodus of Russians from the CER zone. Some went to the Soviet Union; others to the international settlements of Shanghai, Tientsin and beyond. The fate of those who remained lay in the hands of the controlling power - firstly Japan, later the Soviet Union and finally China itself. By the early 1960s, almost all of them had moved on from China.

In the various diaspora communities in which they settled, their lives in China became the defining element of their Russian identity, however removed they had been from the reality of the country in which they had lived. Today, the Chinese authorities are trying to recover and reinterpret Harbin's cosmopolitan past within the new national ethos of a multicultural China and its drive for a global future.

\section{References}

Aurilene, E.E. 2008, Rossiiskaia Diaspora v Kitae, 1920-1950 (The Russian Diaspoa in China, 19201950), Chastnaya Kollektsia, Khabarovsk.

Bakich, O. 2000, 'Émigré identity: the case of Harbin', South Atlantic Quarterly vol. 99, no. 1 (Winter), pp. 51-73.

Balakshin, P. 1958, Final V Kitae (Finale in China), vol. 1, Sirius, Munich.

Berton, P. 1999, 'A trip to Khabarovsk, Birobidzhan, and a nostalgic return to Harbin after fifty seven years', Bulletin of Igud Yotzei Sin (English language supplement), no. 359 (May-June).

Bresler, B. 2000, 'Harbin's Jewish community 1898-1958: politics, prosperity and adversity', in J. Goldstein (ed.), The Jews Of China Volume 2, vol. 2, M. E. Sharpe, New York, pp. 200-215.

Breuillard, S. 2000, 'General V. A. Kislitsin: from Russian monarchism to the Spirit of Bushido', South Atlantic Quarterly, vol. 99, no. 1 (Winter), pp. 128-131.

Breuillard, S. 2004, 'Reviving the Case of Kaspe', International Conference on the History and Culture of Jews in Harbin eds W. Qu \& T. Kaufman, Heilongjiang People's Publishing House, Harbin

Chernolutskaya, E. 2000, 'Religious communities in Harbin and ethnic identity of Russian émigrés', South Atlantic Quarterly vol. 99, no. 1 (Winter), pp. 79-96.

Clausen, S. \& Thøgersen, S. (eds) 1995, The Making of a Chinese City: History and Historiography in Harbin, M. E. Sharpe, New York.

Kaufman, A. 1973, Lagernyi Vrach (Camp Doctor), Am Oved, Tel Aviv.

Kaufman, A.I. 2001, 'Lecture of 17 February 1962', Bulletin of Igud Yotzei Sin, vol. 336, p. 35.

Kaufman, T. 2006, The Jews of Harbin Live on in My Heart, Association of Former Jewish Residents of China in Israel Tel Aviv.

Koga, Y. 2008, “The atmosphere of a Foreign Country': Harbin's Architectural Inheritance ', in A.M. Cronin \& K. Hetherington (eds), Consuming the entrepreneurial city : image, memory, spectacle, Routledge, New York, pp. 221-254.

Lensen, G. 1974, The Damned Inheritance: the Soviet Union and the Manchurian Crisis 1924-35, The Diplomatic Press, Tallahassee.

Levitsky, V.V. 2000, 'Pristan na Sungari’, Bulletin of Igud Yotzei Sin no. 336 (Nov-Dec), p. 47. 
Melikhov, G. 1990, 'Glimpses of Old Harbin', Far Eastern Affairs, vol. 4, pp. 160-164.

Melikhov, G.V. 1991, Manchzhuriya Daliekaya i Blizkaya (Manchuria Far and Near), Nauka, Moscow.

Melikhov, G.V. 1997, Rossiiskaya Emigratsiya v Kitae (1917-1924), Institute of Russian History, Russian Academy of Sciences, Moscow.

Merritt, S. 1998, 'Matushka Rosiia Primi Svoikh Detei! (Mother Russia, Take in Your Children)—archival materials on the Stalinist repression of the Soviet Kharbintsy', Rossiiane v Azii (Russians in Asia) vol. 5, no. Autumn, pp. 207-208.

Moustafine, M. 2002, Secrets and Spies: The Harbin Files, Random House Australia, Sydney.

Moustafine, M. 2004, 'My Family and Its City: Fifty Years in Harbin', International Seminar on the History and Culture of Jews in Harbin, eds W. Qu \& T. Kaufman, Heilongjiang People's Publishing House, Harbin, pp. 364-371.

Pasternak, G. \& Raleigh, E. 1983, To Reach This Season, Judah L. Magnes Museum, Berkeley.

Quested, R.K.I. 1982, 'Matey' Imperialists: the Tsarist Russians in Manchuria 1895-1917, University of Hong Kong, Hong Kong.

Ryan, N. 2005, Rossiya, Harbin, Avstralia (Russia, Harbin, Australia), Russkii Put', Moscow.

Shickman-Bowman, Z. 2000, 'The construction of the Chinese Eastern Railway and the origins of the Harbin Jewish community, 1898-1931', in J. Goldstein (ed.), The Jews Of China, Volume 2, M. E. Sharpe, New York, pp. 187-197.

Stephan, J.J. 1978, The Russian Fascists: Tragedy and Farce in Exile 1925-45, Hamish Hamilton, London.

Taskina, E. 1994, Neizvestnyi Harbin (Unknown Harbin), Prometei, Moscow.

'The White Russians of Manchukuo' 1937, Contemporary Manchuria vol. 1, no. 3.

'Timeline of Orthodoxy in China' 2009, Timeline of Orthodoxy in China, OrthdoxWiki, $2009<\mathrm{http}$ ://orthodoxwiki.org/Timeline_of_Orthodoxy_in_China>.

Vespa, A. 1938, Secret Agent of Japan, Little Brown, Boston.

Wang, Z. 2008, Istoriia Russkoi Emigratsii v Shanhae (A History of the Russian Emigre Community in Shanghai), Russkii Put', Moscow

Wolff, D. 1999, To the Harbin Station: the Liberal Alternative in Russian Manchuria, 1898-1914, Stanford University Press, Stanford, CA.

Working, R. 2001, 'Reminders of Russian Legacy Linger in Harbin', St Petersburg Times 3 April 2001.

Zeng, Y. 2003, The City and Its People: Stories of Harbin Heilongjiang People's Publishing House, Harbin.

\section{About the Author}

\section{Mara Moustafine}

Mara Moustafine is a $\mathrm{PhD}$ student in history at the University of Technology Sydney and a Member of Australia's Refugee and Migration Review Tribunals. She is also senior research associate on the Making Multicultural Australia educational website project and an inaugural board member of the Institute for Cultural Diversity. Bilingual in Russian and English, Mara was born in Harbin, China and grew up in Australia. She holds a BA (Hons) from Sydney University and MA in International Relations from the Australian National University. Her diverse career has included work for the Australian Government as a diplomat and intelligence analyst, as a senior business executive in South East Asia and as National Director of Amnesty International Australia. Her award-winning book, Secrets and Spies: The Harbin Files (Random House Australia, 2002) tells the story of Russians in Harbin through the experience 
of her family who lived there over 50 turbulent years. A Chinese edition was published as Harbin Dang'an (Zhonghua Book Company, 2008). See http://www.maramoustafine.com 



\section{EDITORS}

Mary Kalantzis, University of Illinois, Urbana-Champaign, USA.

Paul James, RMIT University, Australia

\section{EDITORIAL ADVISORY BOARD}

len Ang, University of Western Sydney, Sydney, Australia.

Joanna van Antwerpen, Research and Statistics, Amsterdam, The Netherlands.

Samuel Aroni, University of California, Los Angeles, USA.

Susan Bridges, University of Hong Kong, Hong Kong.

Duane Champagne, University of California, Los Angeles, USA.

Guosheng Y. Chen, RMIT University, Melbourne, Australia.

Jock Collins, University of Technology, Sydney, Australia.

Bill Cope, University of Illinois, Urbana-Champaign, USA.

Heather Marion D'Cruz, Deakin University, Geelong, Australia.

James Early, Smithsonian Institution, Washington, D.C., USA.

Denise Egéa-Kuehne, Louisiana State University, Baton Rouge, USA.

Amareswar Galla, University of Queensland, Brisbane, Australia.

Grethe van Geffen, Seba Cultuurmanagement, Amsterdam, The Netherlands.

Barry Gills, Newcastle University, Newcastle upon Tyne, UK.

Jackie Huggins, University of Queensland, Brisbane, Australia.

Andrew Jakubowicz, University of Technology, Sydney, Australia.

Ha Jingxiong, Central University of Nationalities, Beijing, China.

Jack Levin, Northeastern University, Boston, USA.

Cristina Poyatos Matas, Griffith University, Brisbane, Australia.

Peter McLaren, University of California, Los Angeles, USA.

Joe Melcher, Xavier University of Louisiana, New Orleans, USA.

Greg Meyjes, Solidaris Intercultural Services, Falls Church, USA.

Walter Mignolo, Duke University, Durham, USA.

Brendan O'Leary, University of Pennsylvania, Philadelphia, USA.

Ainwa Ong, University of California, Berkeley, USA.

Peter Phipps, Globalism Institute, RMIT University, Melbourne, Australia.

Ronald Prins, Bos en Lommer Neighbourhood Council, Amsterdam-West, The Netherlands.

Peter Sellars, University of California, Los Angeles, USA.

Michael Shapiro, University of Hawai'i, Manoa, USA.

David S. Silverman, Maryville University, St. Louis, USA.

Martijn F.E. Stegge, Diversity Platform, Amsterdam, The Netherlands.

Geoff Stokes, Institute for Citizenship and Globalisation, Deakin University, Melbourne, Australia.

Terry Threadgold, Cardiff University, Wales, UK.

Mililani Trask, Permanent Forum on Indigenous Issues for the Economic Council of the UN Assembly, Hawai'i, USA.

Marij Urlings, Inholland University, Amsterdam-Diemen, The Netherlands.

Rob Walker, Keele University, Keele, UK.

Ning Wang, Tsinghua University, Beijing, China.

Owens Wiwa, African Environmental and Human Development Agency, Toronto, Canada. 


\section{THE UNIVERSITY PRESS JOURNALS}

\section{The International
JOURNAL Of the ARTS IN SOCIETY}

Creates a space for dialogue on innovative theories and practices in the arts, and their inter-relationships with society.

ISSN: 1833-1866

http://www.Arts-Journal.com

\section{DESIGN PRINCIPLES \& PRACTICES}

Q:

Examines the meaning and purpose of 'design' while also speaking in grounded ways about the task of design and the use of designed artefacts and processes.

ISSN: 1833-1874

http://www.Design-Journal.com

\section{THE GLOBAL STUDIES JOURNAL}

Maps and interprets new trends and patterns in globalisation.

ISSN 1835-4432

http://www.GlobalStudiesJournal.com

\section{The Intermational OU LEARNING}

Sets out to foster inquiry, invite dialogue and build a body of knowledge on the nature and future of learning.

ISSN: $1447-9540$

http://www.Learning-Journal.com

\section{The Intemanaional ${ }_{\text {JUR }}$ INCLUSIVE MUSEUM}

Addresses the key question: How can the institution of the museum become more inclusive? ISSN 1835-2014

http://www.Museum-Journal.com

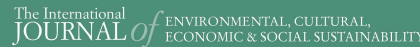

Draws from the various fields and perspectives through which we can address fundamental questions of sustainability.

ISSN: 1832-2077

http://www.Sustainability-Journal.com

\section{UBIQUITOUS LEARNING}

An International Journal

Investigates the affordances for learning in the digital media, in school and throughout everyday life.

ISSN 1835-2030

http://www.ULJournal.com

\section{Tho Intermanional $O f_{\text {ite }} \mathrm{BOOK}$}

Explores the past, present and future of books, publishing, libraries, information, literacy and learning in the information society. ISSN: 1447-9567

http://www.Book-Journal.com

\section{The International
JOURNAL Of DIVERSITY in ORGANISATIONS
COMMUNITIES \& NATIONS}

Provides a forum for discussion and builds a body of knowledge on the forms and dynamics of difference

and diversity.

ISSN: 1447-9583

http://www.Diversity-Journal.com

\section{The Inemational Of in HUMANITIES}

Discusses the role of the humanities in contemplating the future and the human, in an era otherwise dominated by scientific, technical and economic rationalisms.

ISSN: 1447-9559

http://www. Humanities-Journal.com

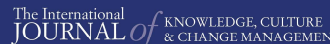

Creates a space for discussion of the nature and future of organisations, in all their forms and manifestations.

ISSN: 1447-9575

http://www.Management-Journal.com

\section{The International}

Discusses disciplinary and interdisciplinary approaches to knowledge creation within and across the various social sciences and between the social, natural and applied sciences. ISSN: 1833-1882

http://www.Socialsciences-Journal.com

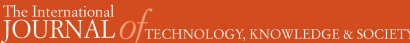

Focuses on a range of critically important themes in the various fields that address the complex and subtle relationships between technology, knowledge and society.

ISSN: 1832-3669

http://www.Technology-Journal.com

\section{JOURNAL of the World Universities Forum}

Explores the meaning and purpose of the academy in times of striking social transformation.

ISSN 1835-2030

http://www.Universities-Journal.com 


\section{The International JOURNAL DIVERSITY in ORGANISATIONS, COMMUNITIES $\&$ NATIONS}

Volume 9, Number 6

Russians from China: Migrations and Identity

Mara Moustafine 
THE INTERNATIONAL JOURNAL OF DIVERSITY IN ORGANISATIONS, COMMUNITIES AND NATIONS

http://www.Diversity-Journal.com

First published in 2010 in Champaign, Illinois, USA by Common Ground Publishing LLC www.CommonGroundPublishing.com.

(C) 2010 (individual papers), the author(s)

(c) 2010 (selection and editorial matter) Common Ground

Authors are responsible for the accuracy of citations, quotations, diagrams, tables and maps.

All rights reserved. Apart from fair use for the purposes of study, research, criticism or review as permitted under the Copyright Act (Australia), no part of this work may be reproduced without written permission from the publisher. For permissions and other inquiries, please contact

<cg-support@commongroundpublishing.com>.

ISSN: 1447-9532

Publisher Site: http://www.Diversity-Journal.com

THE INTERNATIONAL JOURNAL OF DIVERSITY IN ORGANISATIONS,

COMMUNITIES AND NATIONS is peer-reviewed, supported by rigorous processes of criterion-referenced article ranking and qualitative commentary, ensuring that only

intellectual work of the greatest substance and highest significance is published.

Typeset in Common Ground Markup Language using CGCreator multichannel typesetting system

http://www.commongroundpublishing.com/software/ 